Olena Pavlenko,

Ph.D., Associate Professor, Sumy State University, Ukraine

D ORCID ID, 0000-0001-5228-2378

email: o.pavlenko@management.sumdu.edu.ua

Vitalii Sukalenko,

Sumy State University, Ukraine

Oleksii Shkulipa,

Sumy State University, Ukraine

email: caspernumlock@gmail.com

Meena Sunildutt Sharma,

Associate Professor, Dnyansagar Institute of Management and Research,Savitribai Phule Pune University, India

ORCID ID, 0000-0003-2659-4196

email: drmeenasharma.dyp@gmail.com

Correspondence author: email o.pavlenko@management.sumdu.edu.ua

\title{
PERSONNEL MANAGEMENT FEATURES OF MEDICAL INSTITUTIONS
}

Abstract. This article summarizes the arguments and counter-arguments within the scientific discussion on personnel management in health care organizations. The study's main purpose is to identify opportunities to improve the efficiency of medical staff through innovative forms of labor organization and HR management. Systematization of scientific background and approaches on personnel management in health care showed that staff development is a priority in health care. The authors emphasized the high competition in the Ukrainian services market. Thus, improving the service quality is the key element for successful any business activity. The relevance of solving this scientific problem is a need to regulate the organization's personnel policy. To achieve this goal, the study was conducted in the following logical sequence: 1) investigation of the theoretical advances devoted to personnel management of health care facilities and features of this process; 2) analysis of the activity and organizational structure of the University Clinic of Sumy State University; 3) assessment of the motivation and satisfaction of the medical staff of the University Clinic of Sumy State University; 4) identification of the main motives, incentives, and reasons to work; 5) analysis and generalization of the available personnel management tools of the University Clinic of Sumy State University regarding identifying the responsible for personnel management and determining main motivation methods of medical staff. The methodological tools of the study are statistical methods and questionnaires. The study involved data for 2019-2020. The object of the study is the personnel management system of the University Clinic of Sumy State University. The empirical analysis results showed a relationship between several problems, including personnel, organizational and economic. The study empirically confirms and theoretically proves that personnel management affects the effectiveness of health care services. With the study findings, the authors proposed a set of measures to improve the efficiency of the existing personnel management system of the University Clinic of Sumy State University.

Keywords: medical personnel, motivation, organization, health care, management.

Introduction. The organization's operations are impossible without people even though it's innovative or fit with equipment. Indeed, only people can organize the labor process since they are endowed with intelligence, able to think and implement ideas. The personnel management process in health care organizations is multifaceted. Therefore, it is necessary to consider internal problems, substantiate the decisions according to the situation, provide the institution with staff and personal management, and ensure their professional and social development. It stands to note that a medical organization's labor

Cite as: Pavlenko, O., Sukalenko, V., Shkulipa, O., \& Sharma, M. S. (2021). Personnel Management Features of Medical Institutions. Health Economics and Management Review, 1, 44-53. http://doi.org/10.21272/hem.2021.1-05 44 
resources are the staff that constantly on the motion (hiring or firing). Generally, it is quite heterogeneous regarding education, professional experience, age, position, qualifications, etc.

Literature Review. According to the study (Balatsky and Telizhenko, 2009), management is a process that affects the system/organization and ensures the achievement of goals. In turn, Knysh (2014) stated that the modern human resource management concept is a system of theoretical and methodological provisions (principles) that take the growing role of human resources further as an economic resource bringing profit, so a social value of the organization and society as a whole.

The organization follows the principle of priority in achieving the set goals. Herewith, the organization's activity direction and HR management methods are formed in furtherance of these goals. Besides, in this case, the healthcare facilities function like any other organization. Thus, as in any other management system, the medical institutions have the entities that influence the object. It is worth noting that the management objects in health care are as follows:

- $\quad$ municipal health care facilities;

- $\quad$ structural subdivision;

- $\quad$ medical and technical personnel.

Notably, depending on the situation, the personnel management entity in the health care institution could be both the controlling and controlled elements. For example, the deputy chief doctor is the controlling element regarding the organization's doctors. However, regarding the chief doctor, he is the controlled element.

Thera several requirements to the subjects of medical institutions management in health care such as:

- personal, moral, and ethical qualities;

- $\quad$ high professional training, competence, qualification;

- $\quad$ knowledge of basic laws, regulations, local acts, job instructions, legal awareness, etc.;

- team activities are characterized by functionality, complexity, morality, controllability, effectiveness;

- the staff performance is determined by the criteria of patient comfort, optimization of the treatment process, the interest of the doctor, his care for the patient.

Generally, personnel management is a process that influences the performance and development of staff to provide effective institution activity (Dyakiv and Ostroverkhov, 2018). Thus, while forming a personnel management system, it is necessary to consider the institution and the employee goals could differ. Therefore, personnel management activity should minimize these differences (Ivanova, 2017; Kyrpychenko, 2011). The rational activity in health care provides the rational use of human resources. Besides, the efficiency depends on the summation of the cost to ensure favorable working conditions for employees (labor protection, material and technical equipment, safety at work).

Methodology and research methods. The findings on the analysis of the most common methods of personnel management in the Ukrainian medical institutions showed that the economic methods are the main. However, dealing with personnel management involves administrative and socio-psychological methods. Therefore, it suggests the necessity to improve the existing personnel management system in health care institutions. A full set of measures should be used to achieve maximum efficiency of medical institution' personnel management.

Results. Under Provision on the University Clinic of Sumy State University (UC SumDU), a health care institution UC SumDU is a medical-educational-scientific structural unit of polyclinic and outpatient type belonging to SumDU. UC SumDU and is not a legal entity (Provision, 2019).

The main purpose of the clinic is to provide secondary (specialized) and tertiary (highly specialized) medical care; training and retraining of medical staff under higher education standards; conducting 
research; development; testing and implementation of new medical technologies, training students, interns, masters, and clinical residents.

It stands to note the main tasks of UC SumDU are as follows:

- $\quad$ organization and health care delivery to the population;

- $\quad$ enabling conditions for clinical training of students, research and teaching staff, and medical staff within the relevant educational programs;

- $\quad$ improving the education quality and educating students, scientific and pedagogical and medical workers under the medical education standards, providing their practical training.

For performing clinic activities, the university allocated special premises with the necessary medical and diagnostic base. Besides, they meet the requirements of sanitary norms and rules, industry standards of occupational safety, etc.

Notably, the clinic funding sources are the Ukrainian public funds, including own revenues of Sumy State University, such as:

- $\quad$ income from clinic services payment provided under the law;

- $\quad$ the lease of property, which is in the clinic report;

- $\quad$ funds that are accounted for on sub-accounts of other divisions of SumDU (when fulfilling the relevant orders);

- funds from enterprises, organizations, individuals, and other budgetary institutions for the implementation of targeted activities;

- $\quad$ funds from the implementation of economic contracts and grant projects;

- charitable contributions from organizations, enterprises, citizens;

- $\quad$ other sources that do not contradict the current legislation of Ukraine.

To ensure high standards of the diagnostic process and spread laboratory tests spectrum, the UC keeps cooperation going with the official distributor of the world-famous company «Roshe Diagnostics» (Switzerland). That allows using the Roche e411 Cobas analyzer with a patented ElectroChemiLuminescence technology to get high-quality test results quickly (Report, 2020). Besides, the UC SumDU has improved material support and expanded the spectrum of services by purchasing a modern 2-channel Coagulometer K 3002 OPTIC (made by KSELMED, Poland) using the UC SumDU and the Medical Institute subaccounts.

The statistical data showed that in 2020 , the overall number of people who used the UC SumDU services was 8077 people, including 1326 employees and 1,746 students of SumDU.

Table 1. Number of people who used the UC sumdu services

\begin{tabular}{|c|c|c|c|c|}
\hline Service users & 2017 & 2018 & 2019 & 2020 \\
\hline $\begin{array}{l}\text { 1. UC SumDU social service } \\
\text { users }\end{array}$ & 2317 & 4607 (+98\%) & $6335(+37 \%)$ & $3072(-51,5 \%)$ \\
\hline 1.1. Employees & 924 & $2338(+60 \%)$ & $3129(+34 \%)$ & $1326(-57,6 \%)$ \\
\hline 1.2. Srudents & 1393 & $2269(+65 \%)$ & $3206(+41 \%)$ & $1746(-45,5 \%)$ \\
\hline 2. Others & 1098 & $2577(+134 \%)$ & $3180(+24 \%)$ & $5005(+57,3 \%)$ \\
\hline Overall & 3415 & $7184(+110 \%)$ & $9515(+32 \%)$ & $8077(-15,1 \%)$ \\
\hline
\end{tabular}

Sources: developed by the authors on the basis of (Report, 2020).

Therefore, the data analysis showed that compared to 2019 , the total number of UC users decreased by $15 \%$ in 2020 . It could result from the distance working caused the COVID-19 pandemic.

The findings concluded that although the institution's revenues constantly grow, the UC remains unprofitable, showing a negative balance of revenues/expenditures due to upgrading and expanding the 
medical equipment. It stands to mention that the largest UC SumDU cost element was the wage fund 2,02 mln UAH in 2019.

The UC development strategy depends on the planning and management structures corresponding to the clinic's goals, objectives, and programs. Besides, UC interaction with the external environment sets the team management vector to meet staff demands and increase productiveness.

Therefore, the main purpose of the UC SumDU management structure is the timeliness and efficiency of medical services delivery by qualified medical staff. Herewith, the UC activities are organized based on a linear functional management structure assuring the execution of the orders correctly and accurately.

The line manager (chief doctor) is completely responsible for decision-making, subordinating the medical collective. On the other hand, each functional department (treatment and prevention) is responsible for the particular activities, collects and analyzes statistics, extracts reports for the relevant period. Based on the mentioned above, it is clear that only their joint work leads to the high efficiency of the entire organization.

It is undoubtedly that a person is the central unit of life. Therefore, the basis of medical care is public health, care for people, and the national future. However, management should plan the team's work under the lowest labor costs of the organization to provide benefits for both clinic and other stakeholders.

The organizational structure of personnel management in medical organizations is the relationship among rights, duties, functions, and powers in achieving the goals by solving the tasks. In turn, the linear functional management structure provides the linear managers to solve the management tasks. The basis of the linear functional management structure is the management activities specialization by the institution's functional units. Therefore, it suggests a top-down functions hierarchy.

Table 2 presents the advantages and disadvantages of the linear functional management structure.

Table 2. The advantages and disadvantages of the linear functional management structure Advantages Disadvantages

1. The most detailed preparation of tasks and 1. The least interaction at the horizontal level, the solutions regarding employee qualifications. emergence of disputes and conflicts.

2. Delivering central management from the 2. The formal responsibility in pursuit of activities; analysis of problems by units.

3. Involving experts whenever required. different people, make and execute the decisions.

4. Professional motivation in the medical organization management structure. 3. Maximum vertical centralization.

4. Multidisciplinary increases the management workload due to the need to agree on decisions on functional services.

5. Reducing the copy function.

6. Coordinating functional activities.

Sources: developed by the authors on the basis of (Vynograd, 2020).

The management should exactly and clearly set goals and give orders to ensure the rational interaction between all services. On the other hand, the subordinates have to implement the medical organization strategy to carry out orders, perform functional duties under their qualifications, improve their theoretical knowledge and practical skills. As a result, the mentioned above will allow achieving positive results on an urgent basis (Vinograd, 2020)

The effectiveness of UC SumDU depends on its ability to adapt to ever-changing conditions in the competitive market. In addition to that, the findings on competitive analysis allowed identifying the biggest competitors of UC SumDU such as Medical Center «Eledia», Clinic «MedSoyuz», Medical Center «Floris», Medical Laboratory «Synevo» and others. 
It stands to note that the chief doctor carries out the recruitment. However, UC SumDU has no more rational approach to human resource management. Notably, nowadays, the clinic implements several recruitment methods as follows:

- $\quad$ active methods - recruitment from educational institutions (mainly from Medical Institute of SumDU), employment center (presentations, job fairs, etc.);

passive methods - the mass media (ads, advertising, etc.), work demand.

UC SumDU follows two types of motivation such as:

- Material (salary, incentive allowances, bonuses, training, funding from the institution, compensation, etc.). The system of material remuneration includes both fixed and flexible salaries. Thus, the orders determine the payment. Besides, there is a base rate, which varies depending on the position, experience, professional competence (worker's rate).

- Intangible (social protection of workers by trade unions, protection of professional interests, full social package, (contributions to funds), annual full medical examination for the prevention of occupational diseases, 28 calendar days vacation, additional 14 calendar days vacation, career growth, additional education, advanced training, creating comfortable working conditions, etc.).

It is worth emphasizing that the most motivating factor for employees are colleagues' and patients' respect and sense of importance. This study involved the questionnaire of employees to identify their satisfaction with the place and working condition. The total survey sample was 20 employees of UC SumDU. The first stage of this study was to determine the main reasons/motives for the UC SumDU medical staff. The respondents had to choose 5 of the most motivating factors. Figure 1 presents the respondents' answers.

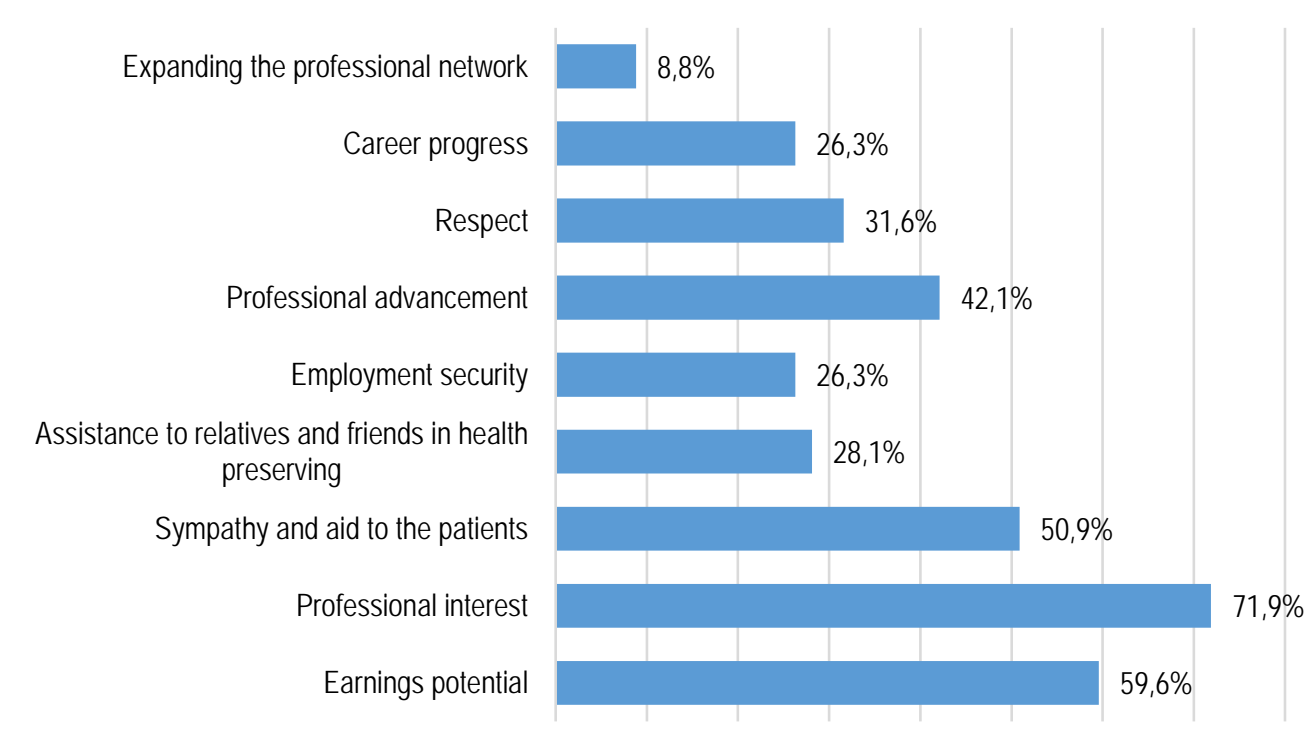

Figure 1. The main motives work at UC SumDU

Sources: developed by the authors.

Thus, the obtained results (Fig.1) showed that the most significant reasons to work for UC SumDU staff were earning potential, professional advancement, empathy, and aid to patients. 
The second stage of this study investigated the most effective motivating factors to work for medical staff at UC SumDU. Similarly to the previous stage, the respondents had to choose 5 of the most influential factors.

In turn, Figure 2 shows the respondents' answers. The findings showed the fair salaries, comfortable working conditions, modern medical equipment, and opportunities for professional advancement were the most effective and influential motivating factors to work.

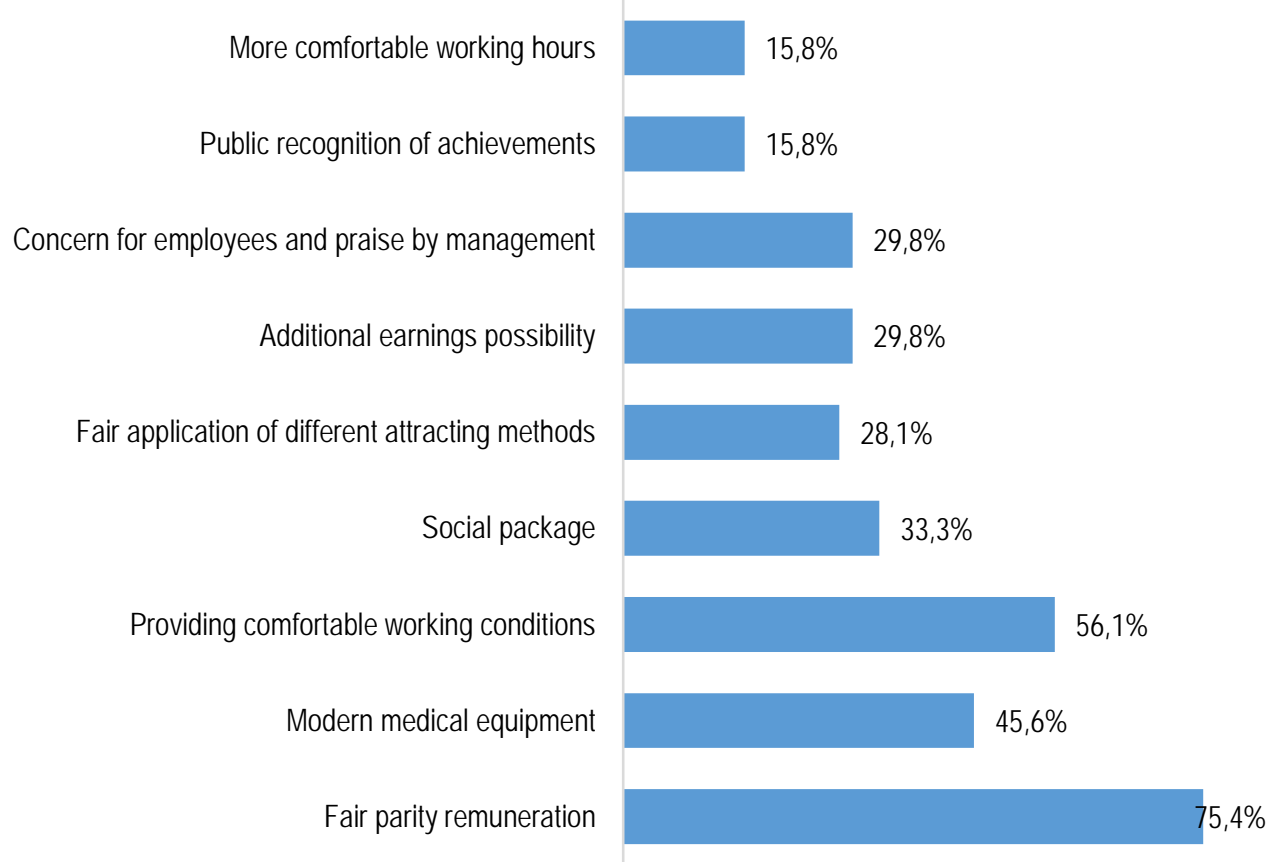

Figure 2. The main incentive factors to work at UC SumDU

Sources: developed by the authors.

The third stage of the study provided the identification of the dissatisfaction causes of medical staff. The respondents had to choose 5 of the most significant causes. Figure 3 demonstrates the respondents' answers.

The analysis of the main cases with work showed that medical staff is most dissatisfied with remuneration and nonmedical work (such as maintaining documentation).

Therefore, the findings allowed identifying several disadvantages and problems in the UC SumDU case, such as:

- $\quad$ organizational problems - personnel planning, training, and retraining;

- $\quad$ financial and economic problems - material dissatisfaction;

- $\quad$ information and technological problems - a need to constantly maintain documentation;

- methodical problems - a discrepancy between used personnel management methods and employees' interests. 


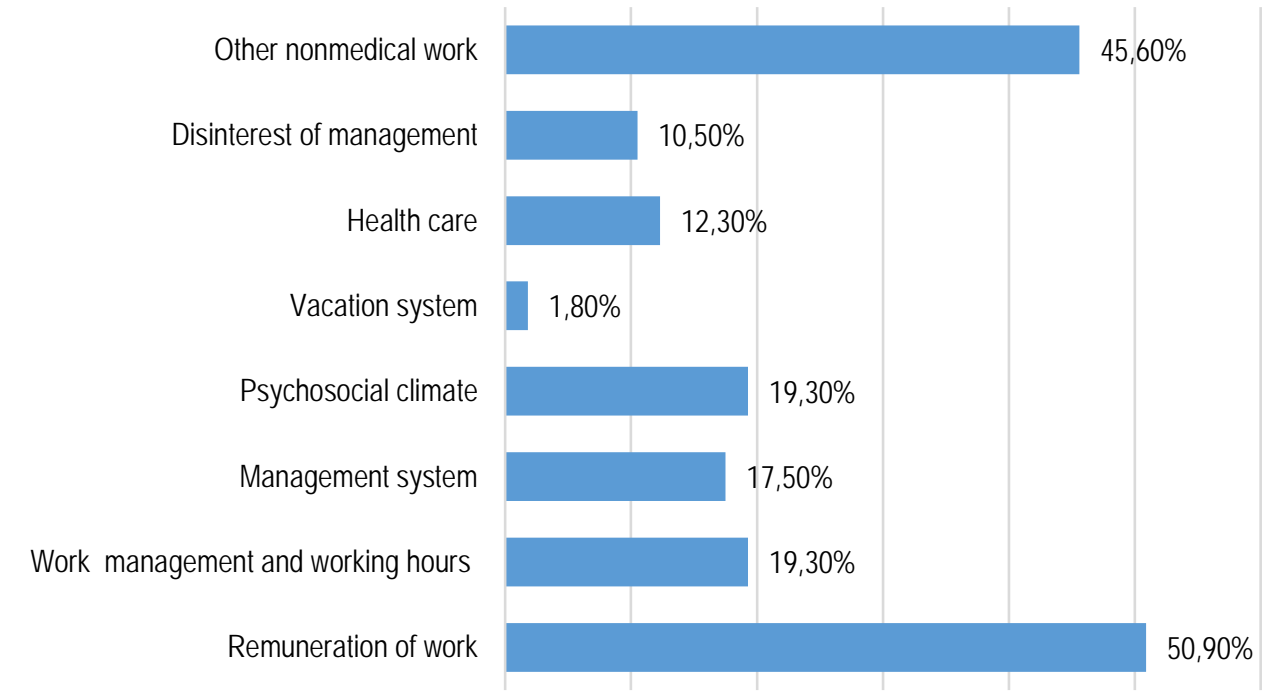

Figure 3. The main causes of work dissatisfaction by UC SumDU medical staff Sources: developed by the authors.

Figure 4 presents UC SumDU personnel management improvement areas based on the current personnel management system analysis findings. Therefore, they could eliminate the identified problems.

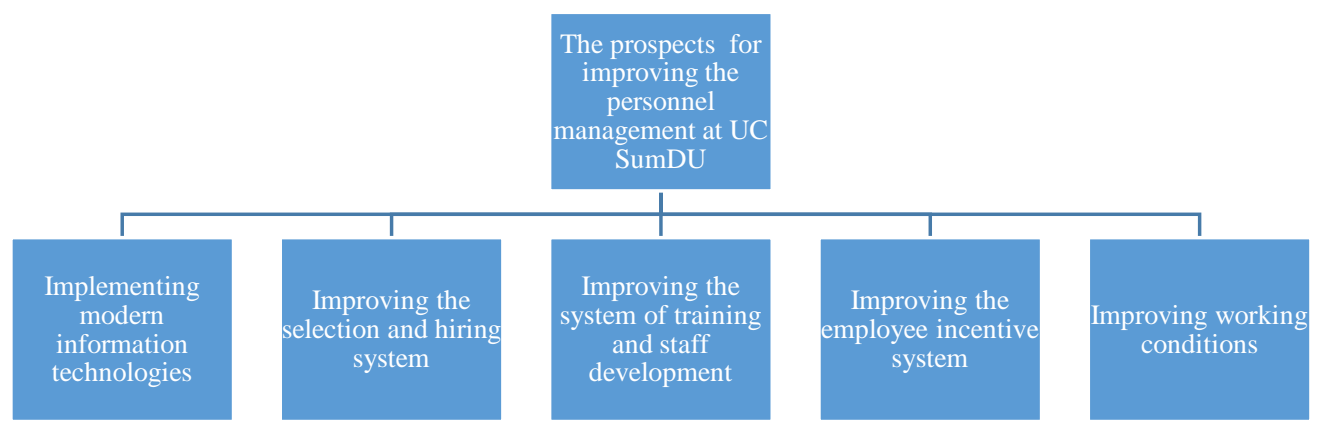

Figure 4. The UC SumDU personnel management improvement areas

Sources: developed by the authors.

1. Implementing modern information technologies would allow:

- improving the documentation management: the algorithm will control gaps in the documentation. The executors will perform collection, systematization, and control of documents. In turn, it will greatly simplify the process of filling necessary documentation by employees and eliminate the negative impact of nonmedical work;

- releasing time for the highest priorities by information access and its exchange. In turn, it is a significant factor in maintaining human health and life; 
- using and access to the patient's database to reduce the time for maintaining paper documentation;

- $\quad$ organizing distance learning and computer testing for employees;

- $\quad$ providing online medical care, etc.

Notably, the medical workers support information technology. In turn, the Ukrainian government constantly develops regulations and legal acts to increase the effectiveness of information technology. Therefore, using information technologies in personnel management systems guarantees the improvement of medical service quality.

2. Improving the selection and hiring system. Notably, the principles of selection and hiring of specialists are essential in forming an effective and qualified team. Improving the personnel management of UC SumDU may include introducing new employee testing and evaluation systems, changing search sources of candidates, and other innovations.

For increasing the efficiency of the recruitment process, it is appropriate to improve the relationship between the Medical Institute of SumDU and the University Clinic by working with students, such as:

- guidance counseling mostly with junior students, since many students doubt the right choice of a particular specialty. In this way, society will get a certified specialist doing the best way in their profession;

- conducting additional optional training to teach students in looking for a job, writing a resume, behaving during an interview, explaining an employment contract and the legality of the trial work period, etc.

3. Improving the system of training and staff development provides - improvement of the lifelong learning concept (self-training, vocational training, retraining, etc.) should include:

- $\quad$ proficiency enhancement of personnel management specialists;

- $\quad$ employee appraisal (competent personnel);

_ $\quad$ planning of social and professional development considering the best practices;

- $\quad$ staff training in digital skills;

- mentoring system.

It should be emphasized that the life-learning concept provides achieving the goals, expanding professional and social excellence, opening new opportunities for staff, etc. Therefore, to be competitive, medical staff has to develop professionally, maintaining social mobility constantly.

4. Improving working conditions. The survey findings showed that in UC SumDU, several employees partially dissatisfied with the working conditions. Thus, to improve the working conditions for medical staff working with modern medical equipment and see patients, it is possible to offer a deeper analysis of the potential risks to the employees' health, namely:

- defining and ranking higher-risk professional group of medical staff to identify priority research areas in occupational medicine;

- developing methodology for assessing the health risk of health care workers under the influence of various factors:

- elaborating on the principles of sanitary-and-bacteriologic examination of modern high-tech medical equipment to ensure its safety for service personnel;

- $\quad$ creating the information programs for medical workers servicing modern equipment, which could be a source of various risks (manuals, brochures, lectures, articles in specialized medical journals, the Internet, etc.);

- $\quad$ implementing the differentiated disease prevention systems.

Therefore, implementing the proposed improvement in personnel management areas would organize and coordinate the medical staff activities more effectively. Besides, considering the foreign experience of 
personnel management in the health care institutions, it is possible to state that the main improvement of the institution's management should relate to personnel management.

Based on the mentioned above, the methods of motivation system improvement could be as follows:

- $\quad$ material incentives (bonuses, additional payment, bonuses) while emphasizing adapted to market conditions additional payments which depend on the staff performance;

- $\quad$ raising in salary, when it is possible;

- $\quad$ intangible incentives (granting subsidized sanatoria and holiday vouchers; improving working conditions by increasing workplace safety, organizing subsidized meals, manager's advertence to the employees' proposals concerning clinic operational process improvement, expressing gratitude and media coverage, authority delegation, etc.).

It is essential to note that by surveying employees on an ongoing basis, management would be familiar with medical staff needs, adjust the motivation system, enhance employee motivation, improve the quality of the medical services, etc. Based on the above, Figure 5 presents the phased implementation of the proposed changes.

\section{Planning}

- Analysis of the average labor costs on the market.

- Analysis of working conditions.

- Analysis of motives and incentives for professional activity.

- Analysis of existing motivation systems.

- Analysis of the satisfaction with the work of medical staff.

- Formation of exact goals and objectives of the medical institution.

\section{Development and approbation}

- Selection of KPI indicators and their specific weight.

- Linking incentive payments with productivity.

- Selection of moral encouragement methods.

- Preparation of the documentation.

Input-output analysis
- Increasing/decreasing patient satisfaction with health care.
- Positive/negative performance dynamic of the medical institution.
As a result: public health improvement

Figure 5. The introduction plan of the proposed changes

Sources: developed by the authors.

Conclusions. This study presents the modern incentive mechanism of medical staff. It includes a set of complementary factors of medical staff incentive, based on a combination of tangible and intangible methods, differentiated assessment of each employee's contribution to the labor process. The basis of material incentive methods is the KPI system, which allows differentiated assessment of each employee's contribution and work quality.

Implementing the proposed mechanism into the personnel management system would positively change the medical institution's activities. Thus, it could improve qualitative and quantitative performance and increase patient satisfaction with the quality and availability of medical services.

Author Contributions: conceptualization, O. P. and M. Sh.; methodology, V. S.; software, O. Sh.; validation, O. P., V. S., O. Sh. and M. Sh.; formal analysis, O. P.; investigation, V. S.; resources, O. P.; 
data curation, O. Sh.; writing-original draft preparation, V. S.; writing-review and editing, V. S. and M. Sh.; visualization, O. Sh.; supervision, project administration, O. P.

Funding: This research received no external funding.

\section{References}

Balatsky, O. \& Telizhenko, O. (2009). Management for Bachelors. Retrieved from [Link]

Dyakiv, O., \& Ostroverkhov, V. (2018). Personal management. Study guide, 288p. Retrieved from [Link]

Ivanova, N. (2017). Personnel management. Lecture course, 140 p. [Link]

Knysh, P. (2014). The modern conceptual approaches to human resource management. Derzhavne upravlinnya ta mistseve samovryaduvannya, 3, 234-244. [Google Scholar

Kyrpychenko, K. (2011). Analysis of the basic enterprise management principles and methods. Management and marketing,

36, 345-347. [Google Scholar]

Law of Ukraine «On Remuneration of Labor» (1995). Retrieved from [Link]

Melnyk, I., \& Razghovorova, A. (2019). Application of Social-Psychological Methods of Collective Management. Modern Economics, 18(2019), 99-105. [CrossRef.

Provision on University Clinic of Sumy State University. (2019). Retrieved from [Link]

Report on performance in sports and recreation activities and health care delivery in 2020. (2020). Retrieved from [Link]

Tserkovna, A., \& Kharlamova, B. (2017). Socio-psychological methods of personnel management. Market economy: modern management theory and practice, 16, 3(37), 222-237.

Typical job description of a university employee in the position of chief physician of the University Clinic. (2019). Retrieved from from [Link

ypical job description of a university employee to carry out his activities as a doctor of the University Clinic. (2019). Retrieved

Typical job description of a university employee to carry out his activities as a nurse at the University Medical Clinic. (2019). Retrieved from [Link]

University CLinic. (2019). The general information about the clinic. University Clinic of SumDU. Retrieved from [Link]

Vynograd, S. (2020). Medical institution management under reforms. Retrieved from [Link]

Олена Павленко, к.е.н., Сумський державний університет (Україна);

Віталій Сукаленко, Сумський державний університет (Україна);

Олексій Шкуліпа, Сумський державний університет (Україна);

Міна Сунілдутт Шарма, Інститут менеджменту та досліджень імені Днянсагара, Університет Савітрібай Фуле Пуна (Індія)

Особливості управління персоналом медичних закладів

Основною метою проведеного дослідження $є$ визначення можливостей підвищення ефекттивності праці медичного персоналу шляхом впровадження інноваційних форм організації праці та управління трудовими ресурсами. Систематизація наукових джерел та підходів до розв'язання проблеми управління персоналом в галузі охорони здоров'я засвідчила, що розвиток кадрів є пріоритетним завданням в галузі охорони здоров'я. У роботі автори наголосили на високому рівні конкуренції на ринку послуг України. Таким чином, покращення якості послуг $є$ головною умовою для успішної діяльності підприємств будь-якої сфери діяльності. Актуальність розв'язання наукової проблеми полягає в необхідності регулювання кадрової політики організацій. Для досягнення поставленої мети, дослідження здійснено $е$ наступній логічній послідовності: 1) досліджено теоретичні основи управління персоналом закладів охорони здоров'я та особливості цього процесу; 2) проаналізовано діяльність та організаційну структуру Університетської клініки Сумського державного університету; 3) оцінено рівень мотивації та задоволеності медичного персоналу Університетської клініки Сумського державного університету; 4) виявлено основні мотиви, стимули та причини праці; 5) проаналізовано та узагальнено наявний інструментарій з управління персоналом Університетської клініки Сумського державного університету, а саме визначено відповідальних за управління персоналом та основні методи мотиваціі медичного персоналу. Методичним інструментарієм проведеного дослідження стали методи статистичного аналізу та анкетування. Періодом дослідження обрано 2019-2020 роки. Об'єктом дослідження є система управління персоналом Університетської клініки Сумського державного університету. Отримані результати емпіричного аналізу засвідчили існування взаємозв'язку між низкою проблем, зокрема кадрового, організаційного та економічного характерів. Дослідження емпірично підтверджує та теоретично доводить, що управління персоналом впливає на ефрективність надання послуг у сфері охорони здоров'я. За результатами проведеного дослідження запропоновано комплекс заходів щодо підвищення ефеективності чинної системи управління персоналом Університетської клініки Сумського державного університету.

Ключові слова: медичний персонал, мотивація, організація, охорона здоров'я, управління. 